\title{
A SPATIAL UNDERSTANDING OF ARCHITECTURE AND THE CITY
}

\author{
Uwe Schröder
}

Let us imagine a work of architecture at the moment of its emergence, merging design with construction, from the originating idea all the way to the keystone, but still without any imputation of a meaningful purpose, without aligning it with the existing location, and without any presuppositions concerning the time that may have elapsed, which is to say, in relation to a "framework," and in the absence of any internal or external "padding,"1 so to speak: at this point, it becomes conceivable that neither "purpose," nor "place," nor "time" is among the attributes of a building, despite the fact that these factors have, more or less, influenced its realization as "external" factors. The external factors determine the "inner" specifications - those concerning "materials," "construction," "form," "function," and "space" - all of which emerge, in turn, as characteristic attributes of the building itself. The essential work of design and construction also consists, then, in transferring such external conditions, by means of the idea, into the architecture, into the building, inscribing them onto its inner specifications. ${ }^{2}$ This is not, however, the time or place to investigate this process further or to reflect upon the significance of the design process, the idea, or this process of transfer: what is pursued here instead is the content of these basic concepts.

In the discipline of architecture today, "space" is perhaps among the most controversial concepts, and perhaps the most ambiguous, too - but why should this be the case? While in previous eras, disputes over the conceptual and contentual determination of "space" were invested with claims to philosophical and physical authority, in the late 19th and early 20th centuries, the discourse on space migrated into various disciplines, among them art history, sociology, phenomenology, and psychology, but the natural sciences in particular. Today, the implications of the term "space" and the theoretical model that underlies it are still being negotiated and affirmed in diverse ways within the various disciplines. It appears that only a transdisciplinary history of the concept could provide insight here, one that would bring together the various "evolutionary" threads of understanding and imagination, meaning and content, and theoretical models and synesthetic perception together in a nuanced way. With the spatial turn in the cultural and social sciences that began in the late 1980s, and also with the succeeding revival of an architectural and theoretical discourse on space, spaces, and spatiality ${ }^{3}$ around the turn of the millennium, a disciplinary differentiation of conceptual terminology has become evident. 


\section{A Spatial Understanding of Architecture}

With regard to architecture, we presuppose here a spatial understanding that attributes to architectural space a phenomenal independence within the differentiated spatiality of the lifeworld, and alongside other natural, cultural, and sociological conceptions of space: architecture situates, "founds and joins" spaces that appear in the interiors of buildings such as courtyards - or among buildings - such as squares - and which, by virtue of the proportional proximity of their structural boundaries, we perceive as inner spaces. Other spaces, such as outer spaces, which, by virtue of the remoteness of their boundaries, have the effect of open, expansive "fields" - such as parks - and do not count as architectural space in the strict sense of the term, although no doubt they contribute to the spatiality of the city.

Architectural spaces appear as place-bound inner spaces that are essentially produced by their structural boundaries. The way in which we are able to move through various spaces within a building, which are connected with one another through openings, corresponds to our everyday experience and perception. However, with this straightforward description of the phenomenon as a perceived event, we have already contrasted the architectural understanding of space to mathematical space, for instance, as well as to other relational conceptions of space. Therefore, we would not refer to "the" space that defines a building, for example, or a city, as a homogenous entity, but instead differentiate between the spaces of a building and, similarly, the spaces of a city according to their appearance.

Among the "primal phenomena" of architecture that pertain to this aspect of space is the "separation of inner from outer." In material, constructive, and formal respects, architecture moves toward the boundary; toward the boundaries between spaces ${ }^{5}$; toward the external boundary between inner and outer initially, which is to say between the interior and exterior of a building; and then toward the internal boundaries between various spaces in the interior of a building. Here, external refers to "being outside," to the situation of being in front of the building, but says nothing, however, about the spatial quality of this situation, since the outside, in relation to the building, may appear as an external space, as an expansive field, or instead as an inner space, as a street or square. In other words, even outside, we may be inside, since even on the outside of a building, architectural spaces can manifest themselves as inner spaces. Nor does the fact that these spaces may not be roofed annul their spatial appearance - as with a courtyard in a building's interior. Architecture creates structural boundaries between spaces, and determines transitions as openings, which may themselves appear as autonomous spaces, a door or a gate, a window or a niche. ${ }^{6}$ Ordinary language also expresses everyday perception, for example, when we use prepositions to refer to the habitual spatiality of a situation: when we speak, for example, of being in the doorway, in the niche, at or in the window, in the room or the hall, as well as being in or on the street.

\section{Excursus: Architectural Modernity and Space}

The oft-misunderstood paradigm shift toward the fourth dimension of space-time, adopted so enthusiastically by modernists, guided architecture toward new interpretive strategies in both praxis and theory. ${ }^{7}$ A far-reaching erosion of the structural boundaries of interior space caused the traditional dialectic of inner and outer to retreat into the background. For 
architecture, this meant a self-imposed renunciation of independent space formation in favor of the formal composition of structural elements, which aimed toward the substantial nullification of the boundary between inner and outer. When this modern development of "spacelessness" in architecture is discussed, ${ }^{8}$ the term should by rights refer to the conceptualized renunciation of the autonomous formation of interior spaces (Figures 1.1 and 1.2). ${ }^{9}$

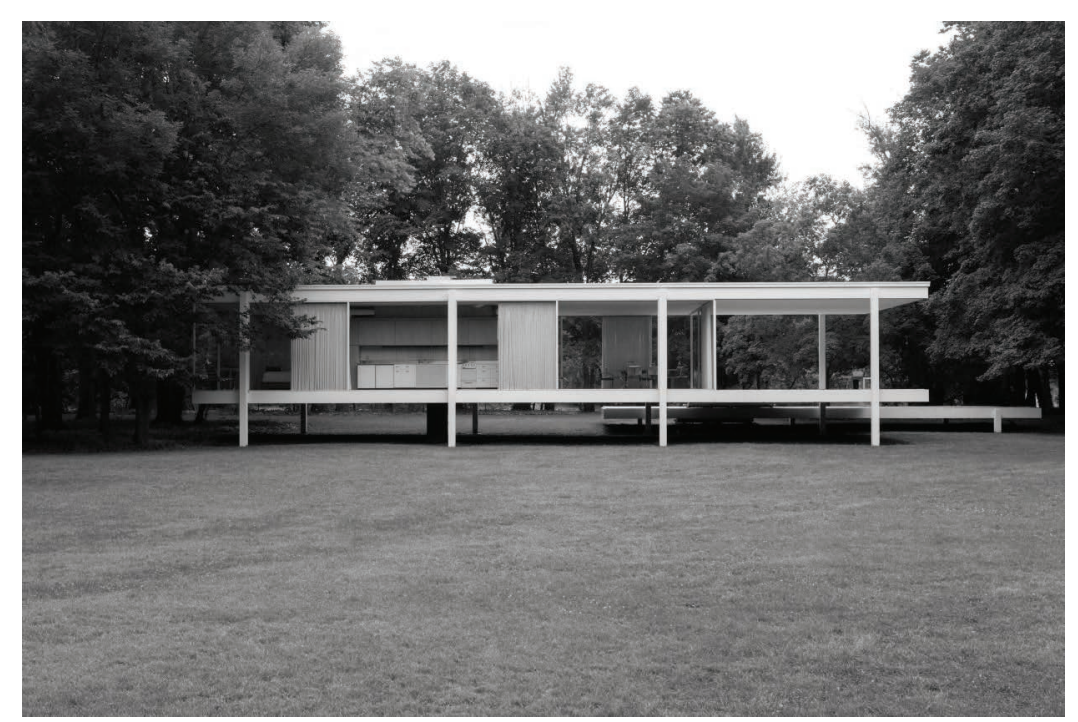

FIGURE 1.1 Ludwig Mies van der Rohe, Farnsworth House (1951), photograph: Yorgos Efthymiadis / yorgosphoto.com.

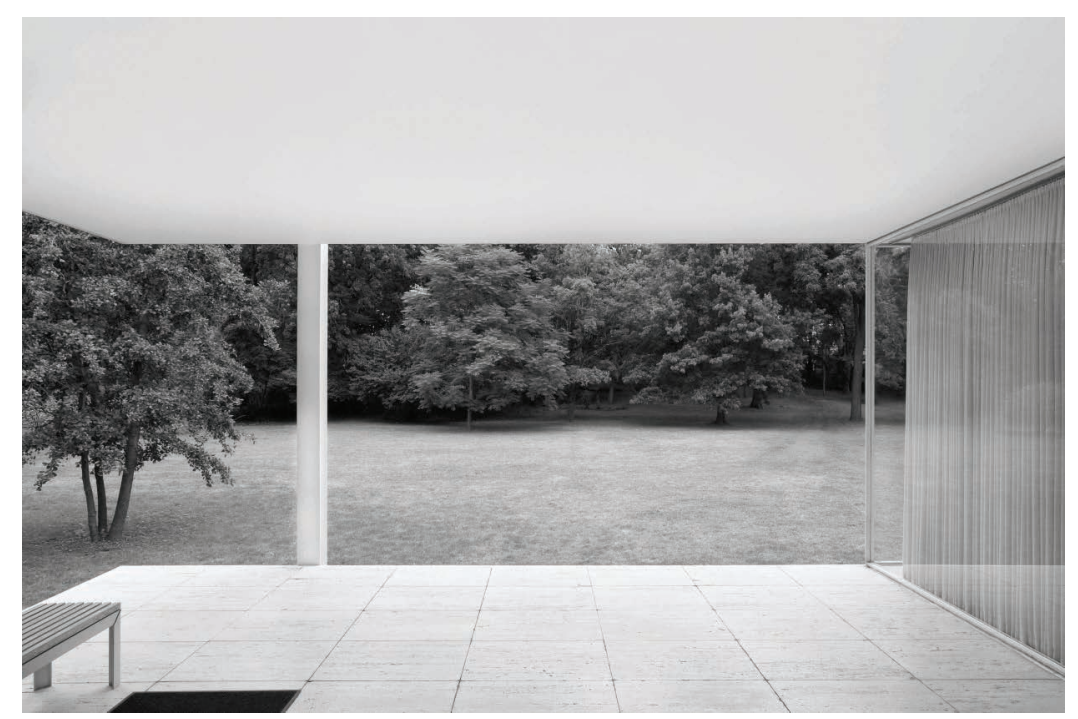

FIGURE 1.2 Ludwig Mies van der Rohe, Farnsworth House (1951), photograph: Yorgos Efthymiadis / yorgosphoto.com. 


\section{A Spatial Understanding of the City}

When we attempt to describe the spatiality of the city from an architectural perspective, we are neither obliged to challenge the architectural understanding of space described here, nor are we obliged to replace the underlying theoretical model, such as by exchanging an absolute concept of space for a relational one. We describe the substantiality of the spaces of the city as perceived spatial situations, which here seem more like inner spaces, and elsewhere more like outer spaces, and which act upon us accordingly. With regard to the inner spatiality of the city, it is worth remarking here that we have at our disposal both a traditional theoretical discourse and a differentiated typology of spaces, one that has generated an encyclopedic collection of references for urban design. Naturally, the same cannot be said for the outer spatiality of the city, since it is not conceived in terms of differentiated spaces, but instead as continuous space, at least in the tradition of architectural modernity. But such a relational conceptualization of space - and this should be self-evident - involves a greater attentiveness to form, to the morphology of built structures, to a city of objects. In order to overcome this inherited conception of space, we would need to imagine, describe, and define the outer spatiality of the city as a city of spaces, too. A typology of the outer spaces of the city would then have the task of introducing a differentiated definition of the meaning of familiar and excessively generalizing terms - those of the cityscape or townscape - and of contributing to a synchronous spatial understanding of the inner and outer spaces of the city (Figures 1.3 and 1.4).

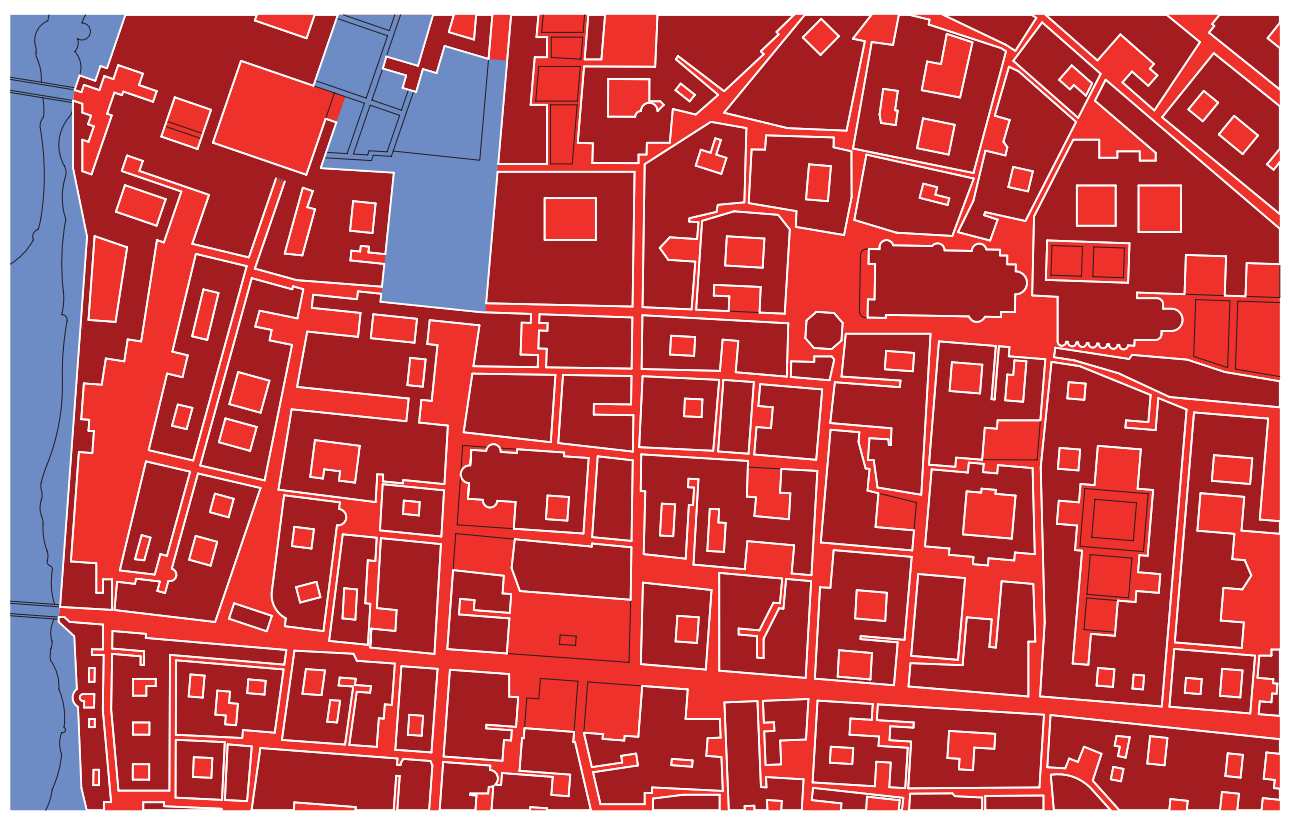

FIGURE 1.3 Parma, red-blue plan, redrawn after: Colin Rowe, Fred Koetter, Collage City, Basel/Boston/Stuttgart 1984, Parma, mass planning, p. 88. From: Uwe Schröder, Pardié: Concept for a City after the Time Regime of Modernity, Cologne 2015, p. 32. 


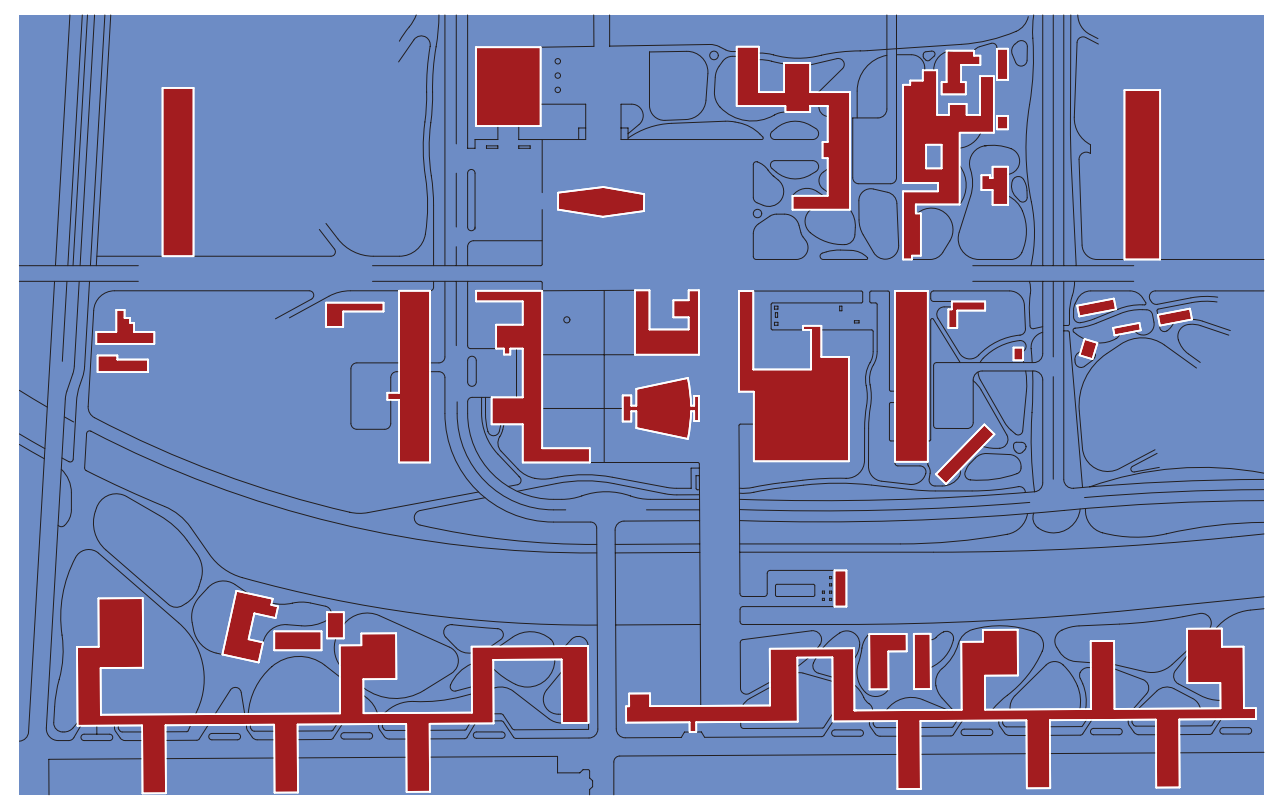

FIGURE 1.4 Saint-Dié, red-blue plan, redrawn after: Colin Rowe, Fred Koetter, Collage City, Basel/Boston/Stuttgart 1984, Saint-Dié, mass planning [Le Corbusier, reconstruction plan for Saint-Dié, 1945], p. 89. From: Uwe Schröder, Pardié: Concept for a City after the Time Regime of Modernity, Cologne 2015, p. 33.

\section{Excursus: Architectural Modernity and the "Open City"}

In opposition to Sitte's aesthetics of urban space, urban planning during this era increasingly took a relational understanding of space as its point of departure: among other things, the opening up of urban spaces was intended to achieve a profound interpenetration between city and landscape. Individual buildings emerged as solitaires, all configured in green spaces that were connoted as hygienic, and which supported a compositional relationship that was not conceived in terms of independent spaces. When we speak - with reference to this modern development in urban planning, whose impact continues up to the present - of the "oblivion of the city," once again referring to a conceptualized renunciation of the autonomous formation of dedicated urban spaces in the form of streets and squares (Figures 1.5 and 1.6). ${ }^{11}$

\section{The Spatiality of Architecture and of the City}

The task of architecture is to facilitate the emergence of dedicated spaces in places. All other definitions - including the aforementioned definitions of inner and outer - aim toward this goal: we build for the sake of these spaces. The spaces we live in, then, are architectural spaces. And what is true of buildings is also true of the city: facilitating the emergence of dedicated spaces in places is also the task of urban planning! It is just that in this instance, we are not only grappling with architectural spaces, which is to say with inner spaces, but also with other spaces at the same time, with outer spaces that require differentiation, in any event, not with space as one homogenous entity. The city of outer spaces is no longer 


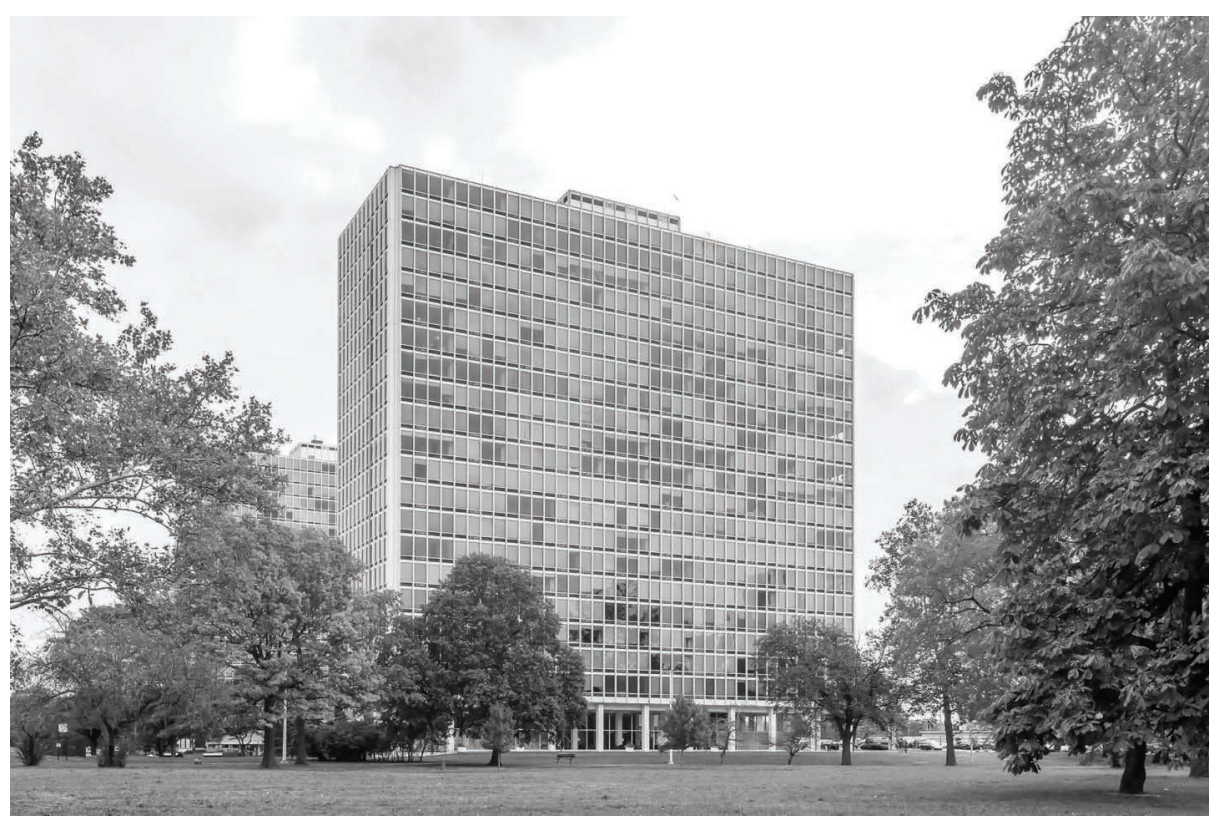

FIGURE 1.5 Ludwig Mies van der Rohe, Lafayette Park (1960), photograph: Fernando Schapochnik.

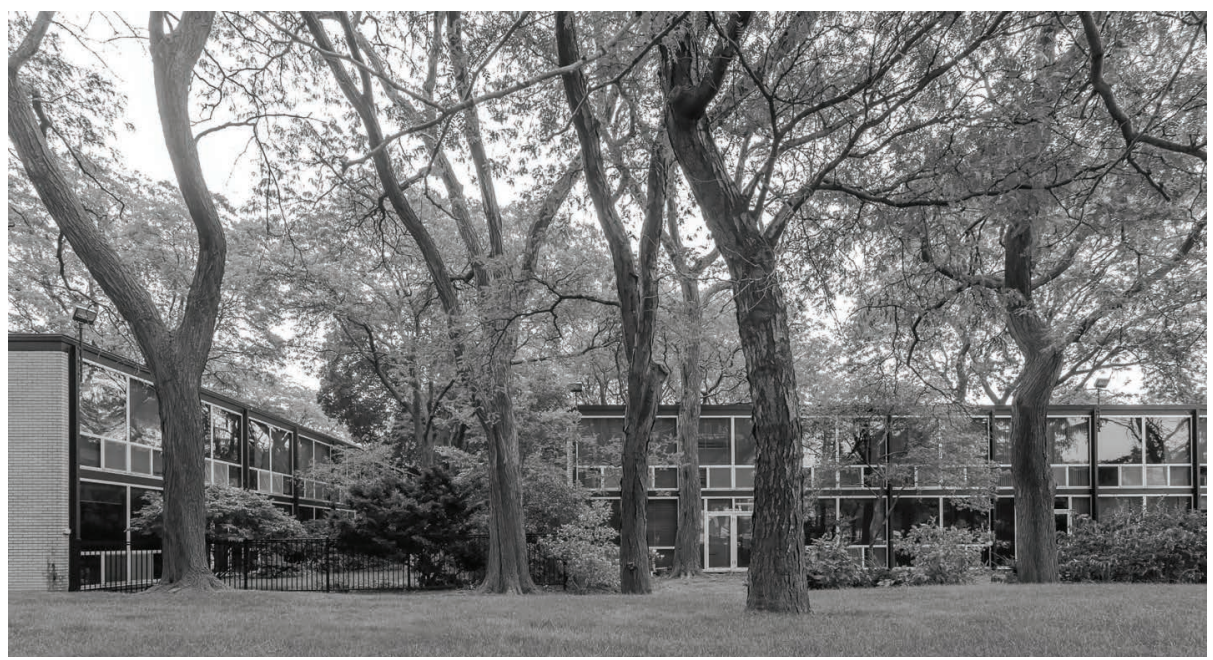

FIGURE 1.6 Ludwig Mies van der Rohe, Lafayette Park (1960), photograph: Fernando Schapochnik.

to be understood as a diffuse continuum, but instead presents itself as a coherent, articulated whole, consisting of situations that are experienced as outer spaces, places, fields, quarters, and urban districts, all of which do justice to the varied characters and atmospheres residing in the "interplay between city and landscape."12 Architecture, then, has the task of explicitly identifying these outer spaces, of delimiting, contouring, and marking them, and of 


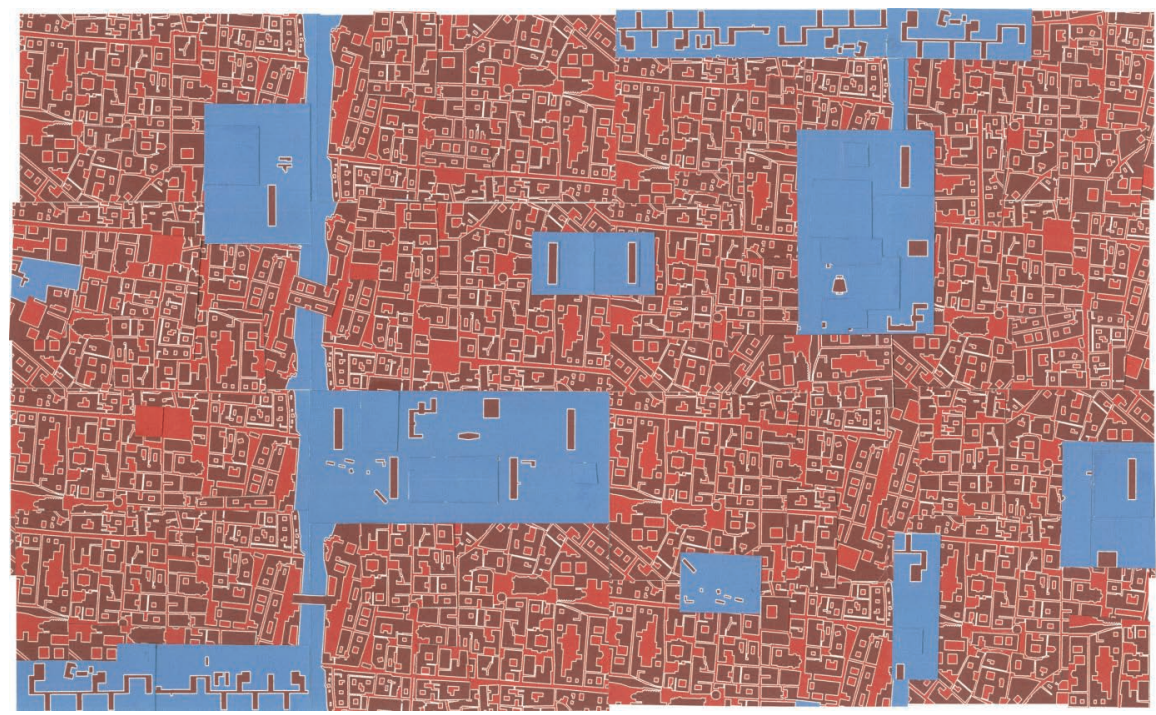

FIGURE 1.7 Pardié (Or: The Reintegration of the Modern City), collage by Uwe Schröder with Matthias Storch, 2015.

shaping transitions between spaces so that they can be experienced in spatial terms, thus guiding the divided urban context toward a "city of spaces" (Figure 1.7). ${ }^{13}$

\section{Notes}

1 "Architecture is a foil for human life, but the two only appear together: in a certain sense, it is the framework (Rahmenwerk) and the padding (Füllwerk) together that form the complete concept of 'architecture'." Sörgel, H. 1921. Architektur-Ästhetik, 3rd ed., Munich. p. 269.

2 See also the special issues of der architekt devoted to the Grundlagen der Architektur: Ort. Grundlagen der Architektur I (der architekt 3/2017); Material. Grundlagen der Architektur II (der architekt 6/2017); Funktion. Grundlagen der Architektur III (der architekt 6/2018); Konstruktion. Grundlagern der Architektur IV (der architekt 6/2019).

3 See the present author: "Verlust des Raumes," in: der architekt 1/2000, Verlust des Raumes, initiated by Denk, A., pp. 19-21.

4 See "Die Korrespondenzen von Leib und Architektur: Urphänomene," in: Meisenheimer, W. 2000. Das Denken des Leibes und der architektonische Raum. Cologne: Verlag der Buchhandlung Walther König. p. 24.

5 See present author, "Die Wand. Grenze der Architektur - Architektur der Grenze," in: der architekt 4/2016, pp. 20-25.

6 Schröder, U. 2016 (see n. 6), p. 20.

7 László Moholy-Nagy, for example, arrived at a relational conception in this way: "Spatial design is the design of the spatial relatedness of bodies," in: idem, von material zu architektur (1929) in: Neue Bauauhusbücher, Wingler, H. M. (ed.), Berlin 2001, pp. 193-211.

8 Present author, "Die eingeräumte Stadt" (2008), in: idem, Die zwei Elemente der Raumgestaltung. Ausgewählte Schriften (2009), ed. the Lehr- und Forschungsgebiet Raumgestaltung, Department of Architecture, RWTH Aachen, Tübingen/Berlin: Wasmuth, p. 69.

9 See explanatory remarks on the "natural science of space," in: Denk, A., Schröder, U., and Schützeichel, R. (eds.) and research assistant Schriner C. 2016. Architektur. Raum. Theorie. Eine kommentierte Anthologie, Tübingen/Berlin: Wasmuth, p. 13.

10 Schröder, U. 2009 (see n. 9), p. 69.

11 Denk, A., Schröder, U., and Schützeichel, R. 2016. (see n. 10), p. 13. 
12 See in particular the collection of outdoor spatial situations in: Lampugnani, V. M., Domhardt, K. S., and Schützeichel R. (eds.) 2014. Enzyklopädie zum gestalteten Raum. Im Spannungsfeld zwischen Stadt und Landschaft. Zürich: gta Verlag.

13 On the terminology of the "city of spaces," see also: Denk, A. and Schröder, U. (eds.) 2014. Stadt der Räume. Interdisziplinäre Überlegungen zu Räumen der Stadt. Tübingen/Berlin: Wasmuth.

\section{Bibliography}

Denk, A. and Schröder, U. (eds.) 2014. Stadt der Räume. Interdisziplinäre Überlegungen zu Räumen der Stadt. Tübingen/Berlin: Wasmuth.

Denk, A., Schröder, U., and Schützeichel, R. (eds.) 2016. Architektur. Raum. Theorie. Eine kommentierte Anthologie. Tübingen/Berlin: Wasmuth.

der architekt. Grundlagen der Architektur: Ort. Grundlagen der Architektur I (der architekt 3/2017); Material. Grundlagen der Architektur II (der architekt 6/2017); Funktion. Grundlagen der Architektur III (der architekt 6/2018); Konstruktion. Grundlagern der Architektur IV (der architekt 6/2019).

Lampugnani, V. L., Domhardt, K. S., and Schützeichel, R. (eds.) 2014. Enzyklopädie zum gestalteten Raum. Im Spannungsfeld zwischen Stadt und Landschaft. Zürich: gta Verlag.

Meisenheimer, W. 2000. Die Korrespondenzen von Leib und Architektur: Urphänomene. In: Das Denken des Leibes und der architektonische Raum, Cologne: Verlag der Buchhandlung Walther König. p. 24.

Moholy-Nagy, L. 1929. Von material zu architektur. In: Neue Bauauhusbücher, ed. Wingler, H. M. 2001. Berlin, pp. 193-211.

Schröder, U. 2000. Verlust des Raumes in: der architekt 1/2000, pp. 19-21.

Schröder, U. 2009. Die eingeräumte Stadt. In: Die zwei Elemente der Raumgestaltung. Ausgewählte Schriften. ed. Lehr- und Forschungsgebiet Raumgestaltung, RWTH Aachen, Tübingen/Berlin: Wasmuth.

Schröder, U. 2016. Die Wand. Grenze der Architektur - Architektur der Grenze. In: der architekt 4/2016, pp. 20-25.

Sörgel, H. 1921. Architektur-Ästhetik (3rd ed.). Munich: Piloty \& Loehle. 